\title{
Marxism, International Law and the Enduring Question of Exploitation: A History
}

\author{
By George Forji Amin*
}

\begin{abstract}
Until the 1990s, there was a longstanding disdain on Marxism amongst jurists especially international lawyers, with non-Soviet international lawyers only paying scant attention or lip service to Marxist thinking, based on a number of misgivings. Firstly, reminiscing of legal history in general, Marxism was perceived as activism reserved for a distant past and irrelevant to the present and future. Secondly, Marxism was long perceived as the prerogative of nonjurists, most especially as Marx himself did not pay attention to jurisprudence. Moreover, Marxism was throughout the cold war period generally associated with the Soviet Union. Any legal analysis from a Marxist perspective was tantamount to being misinterpreted as a defence for Soviet communism-a derogatory position for any scholar in the West at the time. Lastly, although many Soviet publicists did examine Marxism in their studies, Soviet international law was however often excluded from mainstream considerations - and framed as alternative international law rather than conventional discourse. With Soviet International law restricted to rules consented or acquiesced to by states (at least in principle), the Soviet brand of international law was perceived in the West as the most extreme form of positivism.
\end{abstract}

Keywords: Marxist International Law; Capitalism; Exploitation Question; Human Development; Emancipation; Marxist Theory of Law

\section{Introduction}

Is Marxism a human rights or anti-human rights project? As a method, Marxism has established a foothold in academia as an effective modality for explaining social justice by reference to modes of production and exchange. While Marx's critique of political economy is commonplace in social sciences, the reverse is not true with Marxist theory of law. Any legal scholar engaging the works of Marx is bound to grapple with the lack of jurisprudence and failure of the writings tying his analysis to any normative theory of law. In fact, neither Marx nor Engels - his right-hand protégé gave any serious consideration to the role of law in the contradictions of capitalism. Evidently not considered as an essential object of his analysis, Marx failed to accord law any centrality in resolving emanating crisis in social relations. Considering that Marx's work was a robust critique of political economy, one would naturally have expected his analysis to redefine law in such a way as to carter to the exigencies of the working class - the social class for whom he was interceding.

*Dr. of Law( LL.D), Teaching Associate, Faculty of Law, University of Manchester, Manchester, UK; Adjunct Lecturer in International Law, University of Helsinki, Finland. Emails: aminforji@gmail.com; george.forjiamin@manchester.ac.uk; amin.forji@helsinki.fi. 
Until the 1990s, there was a longstanding disdain on Marxism amongst jurists especially international lawyers, with non-Soviet international lawyers only paying scant attention or lip service to Marxist thinking, based on a number of misgivings. Firstly, reminiscing of legal history in general, Marxism was perceived as activism reserved for a distant past and irrelevant to the present and future. Secondly, Marxism was long perceived as the prerogative of non-jurists, most especially as Marx himself did not pay attention to jurisprudence. Moreover, Marxism was throughout the cold war period generally associated with the Soviet Union. Any legal analysis from a Marxist perspective was tantamount to being misinterpreted as a defence for Soviet communism - a derogatory position for any scholar in the West at the time. Lastly, as Bowring has observed, although many Soviet publicists did examine Marxism in their studies, Soviet international law was however often excluded from mainstream considerations - and framed as alternative international law rather than conventional discourse. ${ }^{1}$ With Soviet International law restricted to rules consented or acquiesced to by states (at least in principle), the Soviet brand of international law was perceived in the West as the most extreme form of positivism. ${ }^{2}$

While noting that Marx never developed any systematic theory of law, this paper nonetheless locates the framework of the Marxist theory of law as grounded on Marx's insights on social relations which are scattered throughout his writings on broad notions of justice. I further contend that Marx's critique of political economy while underscoring the scourge of exploitation in the international society, incidentally, showed how international law develops over time. That is, even if Marx did not directly critique law or jurisprudence, he nevertheless through the dialectic of historical materialism unswervingly cantered his studies on social justice and structure of the bourgeois state, thereby revealing the intricate relationship between statehood and human rights violations. It has been observed that Marx's critique was twofold, to wit: a) a critique of bourgeois state, and b) a critique of bourgeois humanism. ${ }^{3} \mathrm{With}$ regard to the first critique, the preeminence which religion once enjoyed and exercised over society had over time been cooped by the sovereign bourgeois state, which had in turn orchestrated a class structure amongst its constituent members. ${ }^{4}$ With regard to the second critique, given that the bourgeois state was founded on theological foundations and abstract liberal doctrines, humans imperatively need to seek emancipation from something higher than religion. ${ }^{5}$

Marxian analyses are imperative for evaluating the ethos and universality of human rights. ${ }^{6}$ His vision of social justice was not only historically driven but moreover a function of class interests (reductionism). His analyses have over the past decades inspired a barrage of reductive forms of analysis of the global

\footnotetext{
${ }^{1}$ Bowring (2008a) at 133-4.

${ }^{2}$ Bowring (2008b) at 12 .

${ }^{3}$ Koskennienmi (2008) at 33-38.

${ }^{4}$ Koskennienmi (2008) at 34.

${ }^{5}$ Koskennienmi (2008) at 35-36.

${ }^{6}$ Marks (2008) at 25; Vincent (1993) at 391.
} 
economic order, amongst dependency theorists. ${ }^{7}$ Employing a reductive concept of justice to critique political economy, Marx clearly saw the capitalist order as unjust and proceeded to outline the parameters of injustice in the system. ${ }^{8} \mathrm{He}$ revisited history and illustrated that capitalism from the onset was borne out of injustice and violence in the fifteenth century, through the forcible removal of peasants from their lands by feudal lords. Now landless, peasants were turned into a life of vagabonds. New laws that were set up to protect the nobility class and their acquired assets, excluded peasants further from rights. ${ }^{9}$

While prevailing literature on political economy focused on abstract political rights, Marx was quick to notice that the approach habitually neglected the interests of the masses. In spite of their strong affirmation for political freedoms, Marx observed that classical enlightenment thinkers before him generally disregarded the dynamics of unfair competition, failed to question the ethics behind profits, and above all, failed to take the plight of the working class into account. In one of many critiques against the philosophy of Proudhon, Marx displayed a total lack of faith on the attainment of justice by enforcing the prevailing laws of his time on commodity production. As he put it, "we may well therefore feel astonished at the cleverness of Proudhon, who would abolish capitalist property by enforcing the eternal laws of property that are based on commodity production."

\section{Legal Review of Marx's Works}

Although various writings of Marx frequently overlap with one another, one scholar ${ }^{11}$ has nonetheless grouped them into four broad categories, to wit: a) works that are philosophically inclined, such as: the Economic and Philosophical Manuscripts (1844), and the German Ideology (1845), b) works that are directed at particular political objectives, such as the Communist Manifesto (1848), c) works informed by historical events, such as $18^{\text {th }}$ Brumaire of Louis Bonaparte (1852), and finally d) works that exemplify systemic economic theories, such as Grundrisse (1858) and all three volumes of Das Kapital (1867-85). With his analysis frequently overlapping in the different texts, contemporary legal Marxists imperatively have to dig across all these four categories in order to discern a Marxist perspective of law.

Despite failing to articulate any normative theory of law, Marx nevertheless offered thorough comprehensive insights on the concept of justice and law,

\footnotetext{
${ }^{7}$ Gilbert (1982) at 329-330.

${ }^{8}$ Wood (1984) at 11.

${ }^{9}$ As Marx put it, "The rapid rise of the Flemish wool manufacturers, and the corresponding rise in the prices of wool in England, gave the direct impulse to these convictions. The old nobility had been devoured by the great feudal wars. The new nobility was the child of its time, for which money was the power of all powers" see Marx (1967) at 718 and "The agricultural people, first forcibly expropriated from the soil, driven from their homes, turned into vagabonds, and then whipped branded, tortured by laws grotesquely terrible, into the discipline necessary for the wage system." Marx (1967) at 737.

${ }^{10}$ Marx (1967) at 427.

${ }^{11}$ Vincent (1993) at 372.
} 
through several writings. Upon establishing firm distinctions between use value and exchange value, proletariat versus bourgeois, and the base versus the superstructure, Marx deconstructed the nature of the right to property in social relations, and determined that law was indeed a false universal. ${ }^{12}$ Despite the consensus amongst academics on the institution of law as in place to safeguard the interests of all constituent members in society, Marx differed and perceived the function of law as one of representing, protecting and promoting the interests of a privileged class - the bourgeois. Considering the transmutation in his analysis over the years - from a progressive ideologue to a radical pragmatist, scholars nowadays frequently review Marx's writings by separating the early works (18421848) from his more mature scholarship (1859-1975). ${ }^{13}$

Prominent early works of Marx span from Debates on the Law of Thefts of Wood $(1842)^{14}$, Critique of Hegel's Philosophy of Right (1843) $)^{15}$, to On the Jewish Question (1844) ${ }^{16}$, and The Communist Manifesto (1848) ${ }^{17}$. As a more mature scholar, Marx published four other groundbreaking works, to wit: Preface to the Critique of Political Economy (1859), Grundrisse (1858), Das Kapital (all three volumes), and Critique of the Gotha Program (1875).

Young Marx (1842-1848)

The Debates on the Law of Thefts of Wood (1842) was an essay which Marx published in five separate segments in Rheinische Zeitung - where he served as Editor-in-Chief. It was in this essay that Marx first articulated his first critique on the conception of private property. The essay explored the injustice faced by ordinary peoples in Germany during his time from the hands of land owners. Even though woods were privately owned, there was nonetheless a longstanding tradition over the centuries, of ordinary peoples walking freely in the bushes and picking fallen logs for firewood and other basic needs. Irritated by these free riders, wood owners in the $19^{\text {th }}$ century increasingly petitioned the state to stop this practice. The state responded by instituting laws protecting private property and barring ordinary peoples from further collecting fallen woods. While the state justified the law on theft of woods on grounds of safeguarding universal interest, Marx observed its enforcement of "universal" interest unfairly tilting in a particular manner. The law on theft of woods is in effect just an instance of how the bourgeois monopolise state apparatus in order to protect self-interests. What is dubbed as universal interest stems from the privatistion of the state by the bourgeois. In his words, "The wood thief has robbed the forest owner of the wood but the forest owner has made use of wood thief to purloin the state itself."

\footnotetext{
${ }^{12}$ Marx essentially saw law as part of the problem, and not the solution to the injustice and exploitation faced by the working class.

${ }^{13}$ Marx, Easton \& Guddat (1997); Elliott (1978).

${ }^{14}$ Marx (1842).

${ }^{15}$ Marx \& O'Malley (1977).

${ }^{16}$ Marx (1975) at 262-3

${ }^{17}$ Marx \& Engels (1967).

${ }^{18} \operatorname{Marx}(1975)$ at 263.
} 
laws protecting private property formally seemed neutral, they had practicallyspeaking been usurped by property owners to defend their self-interests.

The Critique of Hegel's Philosophy of Right (1843) is an article published by Marx in the German Paris-based journal, Deutsch-Französische Jahrbücher, in which he called to question the works of his mentor, Georg Wilhelm Friedrich Hegel (1770-1831) - and most especially, his influential book: Elements of the Philosophy of Right. While Hegel hammered on the importance of Geist (spirit) and religion in a civil society, and used that analysis to formulate a philosophical concept of universal right, Marx viewed the findings as abstractions detached from practicalities. Qualifying the role of Geist in Hegel's work as mystification, Marx borrowed Hegel's concept of alienation ((Entfremdung) and reframed it as a more objective modality for social justice in a human society. ${ }^{19}$

Although Marx adopted the entire frame of Hegel's alienation conception, he nevertheless completely eliminated the idea of absolute spirit from his considerations. Since Hegel's solution for overcoming alienation was basically limited to thoughts, Marx perceived this to be too speculative and abstract. On his part Marx retailored the concept to address the everyday experiences of workers in the age of modernity. Although industrialistion brought about mass production, Marx assumed that success could only be appreciated by examining the nature of production processes that occasioned it. By applying the concept of alienation on historical processes, Marx was able to reveal the plight of the working class in the new industrial age. ${ }^{20}$

It was in the essay On the Jewish Question (1844), that Marx first articulated a materialist conception of history. While criticizing two earlier studies by the young Hegelian, Bruno Bauer on the "Rights of Man", Marx confronted and addressed the question of what it means for a person to be free as a human. In response, he distinguished between political emancipation and human emancipation. While political emancipation to Marx implied freedom as per the law or legal system, human emancipation on the other hand meant being truly free as a human being. While political freedom offered humans essential guarantees (rights of man) such as provisions that all men are free and equal before the law, these guarantees were in practical sense just formal. Real freedom to him was human emancipation - that is, freedom from alienation. ${ }^{21}$ By framing law as a purely formal system, Marx was laying the claim that political emancipation is not true liberation but rather a stumbling block to real human emancipation. Despite claims of political freedoms by many legal systems, the concrete reality of social relations for the vast majority of peoples, Marx observed, was not an enjoyment of human emancipation but their bondage to the economic system.

In the pamphlet The Communist Manifesto (1848), Marx together with Engels to a large degree summed up the key ideas in the afore-noted previous works. The pamphlet is most notable for the elaboration of class struggles and depiction of system of law in human society as bourgeois jurisprudence. "The history of all

\footnotetext{
${ }^{19}$ Marx \& O'Malley (1977).

${ }^{20}$ Marx \& O'Malley (1977) at chapters 1-4.

${ }^{21}$ McLellan (2000) at 88, 91-5, 110.
} 
hitherto existing society is the history of class struggles."22 By the nature of class structure, an oppressive majority (proletariat) is perpetually living in bondage to the whims of an oppressive minority ruling class (bourgeois). The legal system binding everybody as a result is nothing by the will of the bourgeois - who are the ultimate beneficiaries of the capitalist system. The bourgeois state is accordingly just an instance of bourgeois self-interests and manipulations disguised as universal justice. He lambasts the bourgeois ruling class in the following terms: "Your very ideas are but the outgrowth of the conditions of your bourgeois product and bourgeois property, just as your jurisprudence is but the will of your class made into a law for all [...]",23

\section{Mature Marx (1859-1875)}

The Preface to the Critique of Political Economy (1859) was a pamphlet that both complemented the arguments begun in The Communist Manifesto as well as provided an avant goût for Das Kapital. In line with the class struggle introduced in The Communist Manifesto, Marx in Preface to the Critique of Political Economy dwelled on the economic base and the juridical superstructure. While the base encompasses the relations of production and property relations (economic workforce, employer-employee relationship, division of labour, etc.), the superstructure on its part denotes the laws, the state, the political structures, etc., that are built upon the base. Marx contended that the superstructure lacked an autonomy of its own but was instead intrinsically bound to the base.

Grundrisse (1858) published posthumously in 1939 is believed to be the first draft of Das Kapital. ${ }^{24}$ Since its publication, Grundrisse has however been overshadowed by Das Kapital, in part because the volume was not as well polished, and further because of the close overlapping of topics (economic distribution, relations of production, exchange, value, and capitalism) in both works. Marx introduced the metaphor of Robinsonades to mock the liberal abstract notions of right and law. While liberal thinkers espoused for the independence of the individual, they nonetheless failed to observe that production and distribution in social relations are always done collectively and never as an individual act. The valorisation of virtues of independence of the individual favours the bourgeois as an exploitative economic order is vindicated as benign, meanwhile the individuals enjoy nothing else but abstract freedom. In the end, the same societal relations that give rise to the commodity form and capitalism are the same processes that produce the state, law and forms of exploitation.

Of Marx's epic works, Das Kapital is without doubt the most impactful. It critiqued conventional ideals of political economy on liberty and growth by unlocking what academics have now termed as the Lockean Provisio. ${ }^{25}$ The provisio so-to-speak denotes the classical contention of John Locke that everyone is entitled to the products and fruits of their labour. While the provisio at a quick

\footnotetext{
${ }^{22}$ Marx \& Engels (1967) at 2.

${ }^{23}$ Marx \& Engels (1967) at 4-5.

${ }^{24}$ Musto (2008) at Foreword, 1.

${ }^{25}$ Simmons (1994) at 293.
} 
glance seemed quite benevolent and just, Marx observed that because of the way the dynamics of capitalism were structured, the provisio was in practical sense malevolent. Instead of the fruits of their labour, what the working class reaped and experienced in relations of production was often exploitation and unfairness. The question then becomes: how do benevolent promises of everyone enjoying the byproducts and fruits of their labour end up with extensive injustice and exploitation? A reading of Das Kapital suggests that it is as a result of the structure of the economic order and accompanying legal system. Although nominally entitled to the products and fruits of their labour, the working class, deprived of private property are left with no other choice except to trade the only one thing they have left - their labour, to the capitalist for survival. With the economic order structured to benefit the bourgeois class, Marx explains rampant injustice and unfairness are as a result of the laws being squarely implemented, and not because of the failure to enforce the laws. The imbalances in the system unavoidably create rampant poverty - which we have all become accustomed to, amongst the majority exploited class.

While Das Kapital was groundbreaking, the Critique of the Gotha Program (1875) was the one volume wherein Marx crystallised his thoughts and solutions to the problematic of capitalism and alienation, by introducing a two-stage modality of the transition to communism, and by so-doing establishing himself as a seasoned intellectual and revolutionary activist. Having established that social relations of commodity production produces nothing else but bourgeois law, Marx nonetheless observed that given the enormity of the problems orchestrated by capitalism, no society could realistically instantly reverse the capitalist order in a direct revolution and immediately transition to communism. Following the revolution and overthrow of the oppressive bourgeois state, a society was going to need a transitory stage, which he dubbed as "the dictatorship of the proletariat.,"26 During this stage, the society was supposed to be managed by the proletariat for the benefit of the entire masses. Instead of a deceitful bourgeois jurisprudence that only safeguarded the interests of the bourgeois, the proletariat order on the other hand was supposed to institute socialism, abolishing profits, classes and private property. It is only after the proletariat must have purified the society of injustice and exploitation that it could then move to the ultimate second utopia phase dubbed as communism, where both the state and law were bound to wither away. ${ }^{27}$ As Marx sees it, human emancipation is only possible when bourgeois system of law is completely dismantled. Contrary to the Lockean provisio perceived by Marx as a sham, the masses in communist social relations are truly entitled not just to the products and fruits of their labour, but moreover in accordance with their needs.

\footnotetext{
${ }^{26}$ Marx (2008) at 39.

${ }^{27}$ Marx (2008) at 38-39, 55.
} 


\section{Commodity Form Theory of Law}

\section{Pashukanis and the Commodity exchange theory of Law}

The years 1935-1938 were marred by state sanction ruthlessness across the Soviet Union, with an estimated one million to three million government and communist party officials being executed in what became known as the Great Purge. ${ }^{28}$ One of the tragic victims of the carnage was Evgeny Bronislavovich Pashukanis (1891-1937) - a Bolshevik Marxist legal theorist who was indicted by the Soviet Pravda on 20 January 1937, amongst other things with the following treasonous charges: "a Trotsky-Bukarin fascist agent", "a band of wreckers" and "a Trotskyite saboteur". ${ }^{29}$ Having failed to define international law to the satisfaction of Stalin's bureaucracy, Pashukanis who since 1931 served as the Director of Law at the Soviet Academy of Sciences in Moscow, was summarily executed by the Soviet state in September $1937 .{ }^{30}$ Before his purge, he was the leading and most visible Soviet legal theorist both within and withal the Soviet Union, only rivaled by his Protégé, Piotr I. Stuchka who earlier in 1932 passed away at the age of 67.

Pashukanis' seminal work: The General Theory of Marxism and Law ${ }^{31}$ was published in 1924, geared at developing a Marxist theory of law based on Marx's materialist method in Capital, Critique of the Gotha Programme, and related writings. On one hand, the book not only unearthed unprecedented insights into the origins of the legal form in social relations but traced it to be derivative from the commodity form. On the other hand, it underscored the challenges and roadmap which a society was bound to charter for it to transition from capitalism through socialism, to communism. It is a process through which law was going to attain irrelevancy, following a society's maturation to full communism. Unlike Marx who failed to consider any normative theory of law, Pashukanis understood that it was impossible for capitalists to effectuate the complex social relations of exploitation and injustice which Marx rightly spotted, except through the mechanism of law. The indispensability of exchange of commodities in capitalist relations implied that there could be no capitalism except through the operation of law, for the regulation of social relations. To that effect, he identified private law - the regime of contract law to be specific, as the mechanism through which the regulation of private property was conducted. ${ }^{32}$

The General Theory placed Pashukanis at the centre of debates on the relationship between law and the state in social relations. The volume is particularly noteworthy amongst other things for its illumination of what Pashukanis termed as the "Commodity Exchange Theory of Law". The concept, inspired from Marx's analysis of commodities in the first volume of Capital, was

\footnotetext{
${ }^{28}$ Head (2007) at 15.

${ }^{29}$ Bowring (2008a) at 146; Head (2007) at 15.

${ }^{30}$ Hazard (1938) at 246.

${ }^{31}$ Originally published in Russian in 1924, the English translation did not see the day until 1978

- Pashukanis (1978).

${ }^{32}$ Pashukanis (1978) at Chapters 48-50.
} 
developed as a counter-argument to doctrines of international instrumentalism. The concept is to the effect that the exchange of commodities requires private property rights, which in turn accords legal personality to the parties involved in the exchange. ${ }^{33}$ The commodity form as a result has two corresponding angles namely: ownership and exchange. Private property, he observed, generates legal personality through the process of commodity relations. The theory further provides that for commodities to be exchanged, they necessarily have to fulfil three conditions: there has to be established ownership over the commodities for exchange, the right of ownership recognised by both parties, and formal equality of the two owners. ${ }^{34}$

Having defined international law as "the legal form of the struggle of the capitalist states amongst themselves for domination over the rest of the world"35, Pashukanis perceived law as deriving its core form from the nature of commodities operated by capital-producing societies. He constructed the commodity exchange theory of law by evaluating the socio-economic relations between the commodity form and juridical subjects. In the same way that legal subjects are homologous to commodity owners, legal relations by analogy are homologous to commodity exchange. ${ }^{36}$ Given that law enshrines property rights unto juridical subjects in the first place to ensure the exchange of commodities, social relations as a consequence only make sense when they exist for the purpose of exchange. ${ }^{37}$ The exchange of commodities by analogy not only produces a value form but a legal form as well. Upon reaffirming Marx's theory on commodity exchange, Pashukanis observed that there was an analogous nexus between the rationality of the commodity form and the logic of the legal form. In the same way that the concept of exchange value was very vital to Marx vis-à-vis relations of exchange, Pashukanis on his part observed that law is the form in which relations of exchange express themselves. ${ }^{38}$ Not only does the commodity form triumphs where the commodity form defines all social relationships, law is the social form for the realisation of capitalism. ${ }^{39}$

Pashukanis in fact launched his legal career during the period of transition from Vladimir Lenin (1870-1924) to Joseph Stalin (1878-1953) - a time when the Soviet Union was quite tolerant to theoretical debates on socialism. Released at a time when the Soviet Union had just entered the constitutive phase of a socialist empire and thus in dire need of a defining Marxist ideology, The General Theory was very timely in every respect. This is the more so considering that the Soviet regime during this age implicitly required all jurists to tailor their jurisprudence to reflect state practice and the dogmas of the communist party. Despite his groundbreaking findings, the same masterpiece that propelled him to prominence was thirteen years later however sadly going to become the object of his demise.

\footnotetext{
${ }^{33}$ Pashukanis (1978) at Chapter 4.

${ }^{34}$ Pashukanis (1978) at xi, xxiv, 22; Stark (2011) at 200; Marx (1967) at 51.

${ }^{35}$ Pashukanis (1980) at 184-185.

${ }^{36}$ Marks (2008) at 20.

${ }^{37}$ Pashukanis (1978) at 112.

${ }^{38}$ Pashukanis (1978) at 11.

${ }^{39}$ Pashukanis (1978) at 61.
} 
As Stalin increasing became erratic and politically insecure in the 1930 s, so too was the fate of scholars whose writings did not explicitly endorse official state policy and practice. To make matters worse, the release of The General Theory coincided with the publication of Stalin's own thesis on national communism titled: Socialism in One Country (1924). ${ }^{40}$ Upon release, Socialism in One Country became the official guiding instrument driving Soviet economic policy. Contrary to conventional practice by many Soviet scholars at the time, Pashukanis did not tie his General Theory to Stalin's Socialism in One Country.

In effect, Pashukanis' troubles with the Soviet state were twofold. First, he subscribed to the withering away of law and the state for socialism to takeover. He moreover provided that relations of socialist countries with the outside world were regulated by bourgeois law. ${ }^{41}$ Prior to Pashukanis' epic work, Soviet jurists typically considered Marxist thought mostly in terms of class interests embodied in the character of the law. ${ }^{42}$ By placing too much emphasis on class dominationPashukanis observed, many theorists had failed to capture the critical nexus binding law and the economic structure of society. ${ }^{43}$ While other Marxist theorists placed law at the helm of the superstructure of society, Pashukanis showed that law was both a product of the base and the superstructure. ${ }^{44}$ In fact, Pashukanis located his theory on the same spot as Marx - tracing the wealth of capitalist societies to "an immense collection of commodities." ${ }^{\text {D }}$ Dwelling extensively on conceptions of legal subjectivity and commodity exchange, The General Theory afforded new lenses to understand law - as the instrument of mediation between subjects and commodities. It is thanks to the intercession of law that subjects become endowed with juridical rights over commodities, thus conferring these bearer of rights with capacity to exchange commodities.

Unlike other dominant legal theorists of his time, Pashukanis determined that the modern legal form was embodied in the core of capitalism, and functioning in a non-detectable fashion. Almost instantly, The General theory became a useful legal framework for analysing historical materialism. Although the commodity form originates from human needs and creative labour, it nevertheless possesses a "peculiar capacity of concealing its own essence from the human beings who live with it and by it." ${ }^{46}$ In other words, people exploited by the system are blindsided by the structure of their exploitation. The concept of commodity fetishism depicts an ironical reversal of functions - a condition whereby humans who create commodities using their labour become objects, whereas commodities which are the object of human labour become subjects. ${ }^{47}$ Commodities, it has been observed, "appear to take a life of their own, dominating the very human subjects who in fact bring them into existence but who no longer know this."

\footnotetext{
${ }^{40}$ Sandle (1999) at 158.

${ }^{41}$ Chimni (1993) at 247.

${ }^{42}$ Vincent (1993) at 374.

${ }^{43}$ Kamenka (1981) at 27.

${ }^{44}$ Pashukanis (1978) at 104.

${ }^{45}$ Pashukanis (1978) at 85.

${ }^{46}$ Lefebvre (1969) at 47; cf Balbus (1977) at 574.

${ }^{47}$ Balbus (1977) at 574-75.

${ }^{48}$ Balbus (1977) at 574.
} 
Pashukanis concluded that the legal form has historically operated according to a peculiar social form of regulation amongst and between classes, attaining maturity under capitalism. The legal form was bound to come to a dead end in the post revolution communist society, given that classes would have been abolished thus rendering class conflicts redundant. Reviving a position which Marx adopted in his Critique of the Gotha Programme, Pashukanis observed that law was eventually going to wither away with the collapse of capitalism, following the full take-over of the society by universal socialism and socialist production-a moment when exploitation, inequality and injustice were going to become relics of the past. ${ }^{49}$ As to how law was going to eventually wither away, Pashukanis explained that since bourgeois law was imbedded in capitalism, it went without saying that the "the withering away of the categories of bourgeois law will under these conditions mean the withering away of law altogether"

Having established that "only a bourgeois-capitalist society creates all the conditions essential to the attainment of a complete definiteness by the juridical element in social relationships" ${ }^{, 51}$, Pashukanis nonetheless saw no contradiction in the proletariat revolution being administered in the transition period by bourgeois law. He further observed that the Soviet Union was not yet ripe to abolish law altogether. By adopting this position, he countered with those who were advocating for proletariat law. But Pashukanis dismissed this position, contending that there can be no proletariat law, given that law by nature was bourgeois. ${ }^{52}$

All things considered, Pashukanis' General Theory distinguished him from other Marxist legal theorists in two major ways: a) it evidenced the legal form as something much more than just an instrument of class struggle. b) It dispelled the assumption that the bourgeois system of law had been replaced by proletariat law in the post revolution Soviet state.

\section{The Imperativeness of Contracts}

Pashukanis' conviction on the necessity of bourgeois law under capitalist and transitionary orders rested on the importance that he placed on contracts. To him, the legal form finds its true expression in contract law rather than coercion. To him, law derives its essence when a juridical subject entertains relations with another juridical subject on the basis of equality. ${ }^{53}$ Without contracts, Pashukanis contends, "the concepts of subject and of will only exist, in the legal sense, as lifeless abstractions. These concepts first come to life in the contract." freedom and equality are inherent in bourgeois law, he observed, the citizenry by analogy were contractually-speaking subjects of the law, hence "bearers of every imaginable legal claim. ${ }^{, 55} \mathrm{He}$ made two observations with regard to contracts.

\footnotetext{
${ }^{49}$ Anderson \& Greenberg (1983) at 75; Pashukanis (1978) at 61.

${ }^{50}$ Pashukanis (1978) at 61.

${ }^{51}$ Pashukanis (1978) at 110.

${ }^{52}$ Pashukanis (1978) at 50-54.

${ }^{53}$ Pashukanis (1978) at 121; Kamenka (1981) at 26.

${ }^{54}$ Pashukanis (1978) at 121.

${ }^{55}$ Pashukanis (1978) at 119.
} 
First, individuals needed to be free in order to judiciously exchange commodities. Secondly, given that parties in a commodity exchange unavoidably had different interests, it went without saying that disputes were bound to arise. Law as a consequence emerged as the catalyst to regulate and resolve emanating disputes from the contractual relationships. ${ }^{56}$

Pashukanis' observation that conditions of commodity exchange are synonymous to conditions for legal interactions between states, led him to the logical conclusion that rights by nature are commodified. ${ }^{57}$ From the standpoint of Pashukanis, international law evolved side by side with the commodification process, as a catalyst for regulating private interests and dispute settlements. ${ }^{58}$ The term commodification is generally employed by academics to denote a process of turning entities and subjects "into commodities by giving them exchange as well as use value in the marketplace. ${ }^{, 59}$ It was by examining the commodification process that Pashukanis was able to trace social relations of exchange, the legal form and the particularity of law in capitalist producing societies. Rights are not as inherent as often presented but rather privileges which the state accords as it finds fit. Being the principal legal subject of the international society, the exorbitant powers of the state are synonymous to the fetishing of commodities, in that the state not only monopolises rights but can exchange them (through a bargaining process) in ways remising of private individuals with commodities. ${ }^{60}$ The state fetishes its core interests in the same way as commodities.

By analysing commodity exchanges as the basis of the legal form, Pashukanis in fact returned public law to private law contract regime. This was a stark distinction from the prevailing tradition of separating public law and private law as two diametrically opposite regimes. One of the fundamental purposes of law in Pashukanis' conception was the adjudication of conflicts of private subjects, for the common good. ${ }^{61}$ To that effect, he presented the legal form as a regulatory mechanism stemming from a partnership between private and public law, and functioning to promote commodity exchanges. Concurring with Pashukanis on the imperativeness of private law, Ronnie Warrington has noted that private law is not the antithesis of public law but rather its centre of gravity. ${ }^{62}$

Pashukanis' theory further distinguished itself on the analysis of commodification and rights on one hand, and the modality for bestowing property rights unto juridical subjects on the other hand. "At the same time, therefore, that the product of law becomes a commodity and a bearer of value, man acquires the capacity to be a legal subject and the bearer of rights." ${ }^{, 63}$ The exchange of

\footnotetext{
${ }^{56}$ Pashukanis (1978) at 119.

${ }^{57}$ Pashukanis (1980) at 176.

${ }^{58}$ Pashukanis (1978) at 72.

${ }^{59}$ Fletcher (2013) at 139.

${ }^{60}$ Pashukanis (1978) at 73,87 .

${ }^{61}$ Head (2007) at 296.

${ }^{62}$ Warrington (1980) at 105. Pashukanis adopted a similar position, stating that public law "can only be developed through its workings, in which it is continually repulsed by private law, so much that it attempts to define itself as the antithesis of private law, to which it returns, however, as to its centre of gravity." (Pashukanis (1978) at 106.)

${ }^{63}$ Pashukanis (1978) at 112.
} 
commodities to Pashukanis is in fact legally enforceable only where one of the parties in a contract duly recognises the other as owning a thing and entitled to rights thereto.

While many Soviet Economists and lawyers adopted the position that a utopia society could be attained by simply doing away with bourgeois abstract labour, but preserving the proletariat useful labour, Pashukanis being the pragmatist that he was, observed that bourgeois capital could not be completely eliminated. While Pashukanis was a firm believer in the linear communist process that was bound to pass through socialism marked by the withering away of law and the state, Stalin on his part was a believer of a strong state and law. In 1936, Stalin unilaterally declared the Soviet Union as having attained socialism, followed by a draft constitution that same year, which although billed as Marxism-Leninism for the unique purpose of realizing pure socialist aspirations, nonetheless instead legitimated state terror tactics and operations. ${ }^{64}$ The 1936 constitution and Stalin's declaration by implication signaled the strengthening rather than relaxing of state apparatus - a position certainly at odds with Marx's vision for the withering of state apparatus. $^{65}$

\section{Limitations of Pashukanis' theory}

Despite its usefulness, Pashukanis' commodity exchange theory was nonetheless quite general, in at least three levels. Firstly, even though he rightly located the roots of the legal form in commodity exchange, his analysis nonetheless failed to observe that alternative legal forms do emerge through other social modalities. Social relations are formed in many different ways than just economics, such as through politics, sports, entertainment, etc. ${ }^{66}$ Secondly, his conception of the juridical subject as bearer of property rights seemed too general at one end and narrow at another end. Despite the fact that private actors have since the close of the second world war increasingly amass significant rights in the international society, the fact remains that it is states and not individuals who are principal actors of international law. Finally, his theory was so conclusive about legal subjectivity and failed to appreciate or consider any non-propertied channels that could generate rights-bearing standing.

\section{China Mieville and the conception of state as vector of Violence:}

Pashukanis' General Theory has accurately been described as "the kernel of an historical materialist approach to the rise and evolution of the legal form.",67 Despite the 1937 purge and Stalin's immense attempt to liquidate The General Theory from existence, Pashukanis even after seven decades arguably remains the leading Marxian legal theorist the world-over. The General Theory particularly

\footnotetext{
${ }^{64}$ Fine (2002) at 107.

${ }^{65}$ Head (2004) at 270.

${ }^{66}$ Anderson \& Greenberg (1983) at 74.

${ }^{67} \mathrm{Head}(2007)$ at 177.
} 
witnessed a remarkable rediscovery and resurgent revival with the publication of China Mieville's epic book: Between Equal Rights (2005), wherein he revived and reframed the erstwhile commodity exchange theory of law as "the commodity form theory of Law".

Just as was the case in the days of Pashukanis, Marxist jurists even nowadays typically align themselves within one of two juridical streams, namely: instrumentalism or reductionism and formalism. While instrumentalists conceive law or legal order as an instrument of the powerful geared at fostering their will in society, formalists on their part consider the legal order as an autonomous structure deriving its essence from its own internal dynamics. ${ }^{68}$ In other words, whereas instrumentalists contend that the legal order neither possesses self-autonomy nor have a will of its own but rather functions according to "the demands imposed on it by actors of the capitalist society on which it is imbedded,"69 formalists conceive law as autonomous from class interests. The choice ultimately rests on "absolute legal subservience to the relations of production and absolute legal autonomy from them." 70

Upon agreeing with Pashukanis that the logic of the commodity form is analogous to the logic of the legal form, Mieville reaffirms the classical Marxist conditions necessary for the legal form during a commodity exchange: "each commodity must be the private property of its owner, freely given in return for the other...Therefore, each agent in the exchange must be i) an owner of private property, and ii) formally equal to the other agent. Without these conditions, what occurred would not be a commodity exchange? The legal form is the necessary form taken by the relations between these formally equal owners of exchange values." 71

Without a normative theory of law, Mieville observed, "the specificity of law itself is impenetrable." ${ }^{, 72}$ Despite agreeing with Pashukanis on the roots of the legal relations as grounded on commodity exchange, Mieville nevertheless digressed significantly with him on the central form by embracing the instrumentalist socialist theory of coercion as a core kernel in the nature of the commodity form. While Pashukanis perceived commodity exchange and emanating legal relations as non-violent, Mieville on his part contended that commodity exchanges amongst juridical subjects stringently derive their basis from coercion. If it is true that the ruling class in capitalist producing societies generally amass political power and economic control through force as frequently contended by Marxists, then it goes without saying that it was really somewhat surprising that a prominent Marxist legal theorist such as Pashukanis could not detect coercion in the bourgeois law.

The deviation from Pashukanis' postulation compelled Mieville to treat international law as a violent hegemonic project unlike Pashukanis who despite underlining the exploitative nature of the legal form and envisaging the withering of law in the long run, nevertheless still perceived international law as non-violent

\footnotetext{
${ }^{68}$ Balbus (1977) at 571-572.

${ }^{69}$ Balbus (1977) at 571.

${ }^{70}$ Koen $(2011)$ at 110 .

${ }^{71}$ Miéville (2008) at 78.

${ }^{72}$ Miéville (2008) at 2.
} 
progressive project. To Mieville, "the chaotic and bloody world around us is the rule of law." ${ }^{, 73}$ As to why coercion is inevitable in the commodity form, Mieville turned Pashukanis' theory on contracts over its head, observing that this stemmed from the fact that actors in a commodity exchange naturally nurse conflicting interests, thus increasing the likelihood of dispute settlements:

Violence-coercion-is at the heart of the commodity form, and therefore the contract. For a commodity meaningfully to be 'mine-not-yours'-which is, after all, central to the fact that it is a commodity to be exchanged-some forceful capabilities are implied. If there were nothing to defend its 'mine-ness', there would be nothing to stop it becoming 'yours', and when it would no longer be a commodity, as I would not be exchanging it. ${ }^{74}$

Mieville's work essentially revives and expands on familiar questions of violence and power politics by academic writing on imperialism. Without violence, he contends, "there could be no legal form", just as there would correspondingly be no international law without imperialism. ${ }^{75}$ One scholar has however disagreed with Mieville's assertion, contending that there are many other reasons that compel subjects of international law to respect private property regimes. Some of these factors include inter alia, "economic reasons (if you steal someone's property they will not trade with you again) or ideological reasons (you genuinely believe that private property is sacrosanct) for abstaining from theft."

While publicists typically espouse international law as having transformative potentials to regulate the international society, Mieville strongly doubts these predispositions, and instead projects the discipline as marred by indeterminacy, legal subjectivity and violence. ${ }^{77}$ As he sees it, peaceful relations are only possible as long as conditions are profitable to property owners. Were conditions to be otherwise, Mieville's reading of Marx is that property owners would unfailingly resort to their last resort, namely, force: "between two equal rights, force decides." ${ }^{, 78}$ Only powerful states are capable of deploying sufficient force necessary to back up their particular interpretation of the law. ${ }^{79}$

Coercion as conceived by Mieville is expressed by military violence, either directly or indirectly as a deterrence. Mieville's coercion claim is partly useful for elucidating the exploitation of third world resources by powerful industrialised countries. Considering that violence is intrinsic in the commodity form, it follows that those powerful countries in need of economic resources would unfailingly deploy both fair and foul means to acquire commodities in distant territories, badly

\footnotetext{
${ }^{73}$ Mieville (2008) at 132 ; Miéville (2004) at 319.

${ }^{74}$ Miéville (2004) at 126.

${ }^{75}$ Mieville (2008) at 127.

${ }^{76} \mathrm{Knox}(2009)$ at 425.

${ }^{77} \mathrm{Knox}(2009)$ at 413.

${ }^{78}$ Mieville borrowed the title of his book from an observatory statement by Marx in Capital I: "the normal working day is the result of a struggle between capital and labour. 'Between equal rights force decides.'(Marx (1967) at 151. Mieville borrowed the title from Marx. See Marx $(1967)$ at 344.

${ }^{79}$ Knox (2009) at 418.
} 
needed to stimulate economic growth. On the flip-side, meanwhile Mieville mostly conceives such force in brute terms, in reality, many commodity relations between countries despite their asymmetric differences, are pacific in nature. It is often doubted why the third world despite their numerical advantage hardly ever successfully challenge the hegemony of powerful states especially at the United Nations. A reading of Mieville suggests that it is because unlike powerful states, third world countries naturally lack the capacity to back their worldview with force. In his words:

Intrinsically to the legal form, a contest of coercion occurs, or is implied, to back claim and counterclaim. And in the politically and militarily unequal modern world system, the distribution of powers is such that the winner of that coercive contest is generally a forgone conclusion. ${ }^{80}$

To Mieville, imperialist violence is always structural. In Capital III, Marx sought to unveil the hidden secret of the state in social relations, tracing its core essence in the commodity form of production:

It is in each case the direct relationship of the owners of the conditions of production to the immediate producers... in which we find the innermost secret, the hidden basis of the entire social edifice, and hence also the potential form of the relationship of sovereignty and dependence, in short, the specific form of the state in each case. ${ }^{81}$

Although states traditionally intercede on behalf of the citizenry, Mieville observes that the structural essence of states and the basis of social relations are grounded on the specific form of commodity production. While reaffirming Pashukanis, Mieville observed that the same "conditions required for commodity exchange are the conditions required for legal interactions between states." ${ }^{, 22}$ These conditions include conceptions of private property and ownership on one end, and legal rules for their protection and promotion on another end.

Noting that "Grotius transferred the notion of liberty-as-property to the state in international affairs, viewing the character of state boundaries as that of a private estate", Mieville insinuates that States just like individual private property owners, interact amongst one another in the international society as property owners of their territories - having consolidated their power "in a context of increasing international interaction and conflict." ${ }^{, 83}$ States treat one another as commodity owners when they conduct international trade. ${ }^{84}$ With states being the principal actors of international law and the standard frame for universal expression, the discipline is perceived to derive locus standi when two conditions are met, to wit: a) when a sovereign can legitimately lay claim to a territory (own a territory), and b) when the sovereign acquires the capacity to trade and interact with other sovereigns. Mieville's work in fact reveals International law as

\footnotetext{
${ }^{80}$ Miéville (2004) at 292.

${ }^{81}$ Marx (1966a) at 927.

${ }^{82}$ Marks (2008) at 20. [Citing Mieville].

${ }^{83}$ Miéville (2004) at 96, 109,

${ }^{84}$ Miéville (2004) at 191
} 
conceptualizing state entities not only as owners of their territories but moreover as determining rights and obligations based on this understanding.

Contrary to formalists, Mieville indeed does not see the state as a neutral entity but rather as an element of the ruling class. Why does the ruling class always resort to law when it comes to power? For classical Marxists, both the state and laws are weapons at the disposal of the governing class to advance the interests of bourgeois in relation to other classes. Law is quintessentially a manifestation of the state's readiness to enforce its interests through coercion. ${ }^{85}$ This explains the coercive character of the law in the commodity form:

The problem is actually intractable. In the commodity-form theory, law is simultaneously a form inheriting between two free, abstract individuals and a necessary subjection to coercion. For this reason, there is no neat solution. It is not the legal theory which is paradoxical, but the relations that it represents. ${ }^{86}$

\section{Conclusion}

It is fair to assume that it was the flagrant shortcomings of prior enlightenment thinkers that compelled Marx to offer an alternative account of political economy. He importantly demonstrated that contrary to conventional givens, social justice was in actuality dependent on relations of production: "the justice of transactions which go on between agents of production rests on the fact that these transactions arise as a natural consequence of the relations of production." ${ }^{87}$ While unravelling the contradictions in the essence of capital, Marx was in effect presenting himself both as a representative and the voice of the working class-better still, the advocate for their human rights. That is why despite showing at length the pervasiveness with which law and order co-existed with inequality and exploitation in human societies, he remained focused on the possibilities of human emancipation from exploitation. Having tacitly expressed an immense lack of faith in human law, Marx while distinguishing human freedom from political freedom envisaged an emancipatory revolution as the only modality to cleanse society and guarantee social justice. ${ }^{88}$ While international law has steadily come to terms with aspects of Marxism during the last three decades especially on questions of human rights, there has been obvious uneasiness amongst international lawyers with his discourse of revolution perceived by many as antithesis to the very spirit of law. Evidently, legal reforms assume the guise of evolution rather than revolution.

\footnotetext{
${ }^{85}$ Mieville (2008) at 104.

${ }^{86}$ Miéville (2004) at 149.

${ }^{87}$ Marx (1966a) at 339-40.

${ }^{88}$ Marx (1993) at 87-88.
} 


\section{References}

Anderson, E.N. \& F.D. Greenberg (1983). 'From Substance to Form: the Legal Theories of Pashukanis and Edelman' in Social Text 7:69-84.

Balbus, I. (1977). "Commodity Form and Legal Form: An Essay on the "Relative Autonomy" of the Law' in Law \& Society Review 11:140-148.

Bowring, B. (2008a). 'Positivism Versus Self-determination: The Contradictions of Soviet International Law' in Susan Marks (ed.), International Law on the Left: Reexamining Marxist Legacies. Cambridge: Cambridge University Press.

Bowring, B. (2008b). The Degradation of the International Legal Order? The Rehabilitation of Law and the Possibility of Politics. New York: Routledge.

Chimni, S.B. (1993). International Law and World Order: A Critique of Contemporary Approaches. New Delhi: Sage.

Elliott, J.E. (1978). 'The Grundrisse as Social Theory: Link between Young Marx and Mature Marx' in Social Science Quarterly 59:239-256.

Fine, R. (2002). 'Marxism and the Social Theory of Law' in R. Banakar \& M. Travers (eds.) An Introduction to Law and Social Theory. Oxford: Hart.

Fletcher, R. (2013). 'Legal Form, Commodities and Reproduction: Reading Pashukanis' in M. Drakopoulou (ed.) Feminist Encounters with Legal Philosophy. London/New York: Routledge.

Gilbert, A. (1982). 'An Ambiguity in Marx's and Engel's Account of Justice and Equality' in The American Political Science Review 76:328-346.

Hazard, N.J. (1938). 'Cleansing Soviet International Law of Anti-Marxist Theories' in American Journal of International Law 32:244-252.

Head, M. (2004). 'The Rise and Fall of a Soviet Jurist: Evgeny Pashukanis and Stalinism' in The Canadian Journal of Law and Jurisprudence 17:269-294.

Head, M. (2007). Evgeny Pashukanis: A Critical Reappraisal. London: Routledge.

Kamenka, E. (1981). 'Marxism, Economics and Law' in ASLP Bulletin 20:14-45.

Knox, R. (2009). 'Marxism, International Law, and Political Strategy' in Leiden Journal of International Law 22:413-436.

Koen, R. (2011). 'In Defence of Pashukanism' in Potchefstroomse Elektroniese Regsblad 14:104-169.

Koskennienmi, M. (2008). 'What Should International Lawyers Learn from Marx', in S. Marks (ed.) International Law on the Left: Re-examining Marxist Legacies. Cambridge: Cambridge University Press.

Lefebvre, H. (1969). The Sociology of Marx. New York: Vintage Books.

Marks S. (2008). International Law on the Left: Re-examining Marxist Legacies. Cambridge: Cambridge University Press.

Marx, K., Easton, L.D. \& H.K.Guddat (1997). Writings of the Young Marx on Philosophy and Society. Indianapolis: Hackett Publishing.

Marx, K. (1842). 'Debates on the Law of Thefts of Wood' in Rheinische Zeitung Nos. 298, 300, 303, 305 \& 307, of October 25, 27 \& 30, November 1, 3, 1842.

Marx, K. (1966a). Capital, Vol. 3: The Process of Capitalist Production. Moscow: Progress Publishers.

Marx, K. (1966b). The Poverty of Philosophy. Moscow: Progress Publishers.

Marx, K. (1967). Capital: Critique of Political Economy. New York: International Publishers.

Marx, K. (1975). 'Debates on the Law on Thefts of Wood' in Marx K \& F. Engels Collected Works, Vol. 1. London: Lawrence and Wishart.

Marx, K. (1993). Grundrisse (translated by Martin Nicolaus). London: Penguin Books. 
Marx, K. (2008). Critique of the Gotha Program. Rockville, Maryland: Wildside Press.

Marx, K. \& Engels, F. (1967). The Communist Manifesto, translator Samuel Moore. London: (Penguin..

Marx, K. \& O'Malley J. (1977). Critique of Hegel's' Philosophy of Right. Cambridge: Cambridge University Press.

McLellan, D. (ed.) (2000). Karl Marx: Selected Writings. Oxford: Oxford University Press.

Mieville, Ch. (2004). Between Equal Rights: A Marxist Theory of International Law. London: Brill.

Mieville, Ch. (2008). 'The Commodity Form Theory of International Law' in S. Marks (ed.), International Law on the Left: Re-examining Marxist Legacies. Cambridge: Cambridge University Press.

Musto, M. (2008). Karl Marx's Grundrisse: Foundations of the Critique of Political Economy 150 Years Later. London/ New York: Routledge.

Pashukanis, E.B. (1978). Law and Marxism: A General Theory (translated by B. Einhorn). London: Ink Links.

Pashukanis, E.B. (1980). Selected Writings on Marxism and Law. London: Academic Press.

Sandler, M. (1999). A Short History of Soviet Socialism. London: Taylor \& Francis.

Stark, B. (2011). 'What's Left?' in George Washington International Law Review 42:191215.

Simmons, A.J. (1994). The Lockean Theory of Rights. New Jersey: Princeton University Press.

Warrington, R. (1980). 'Debate: Standing Pashukanis on His Head' in Capital \& Class 4:102-106.

Wood, W.A. (1984). 'Justice and Class Interest' in 93 Philosophica 93:9-32.

Vincent, A. (1993). 'Marx and Law' in Journal of Law and Society 20:371-397. 
